DE DE GRUYTER OPEN
Research Article

(C) 2018 Antonella Colonna Vilasi. This is an open access article licensed under the Creative Commons Attribution-NonCommercial-NoDerivs License (http://creativecommons.org/licenses/by-nc-nd/3.0/).

\title{
Israel and the Middle East: The creation of a Nation
}

\section{Antonella Colonna Vilasi ${ }^{1}$}

University Centro Studi UNI

Doi: $10.2478 / m j s s-2018-0047$

\section{Abstract}

In order to properly study the foundation of a State, a paradigm of thought or any other organization, we should analyze the historical context which produced the conditions for this phenomenon to happen, in all its variables and components. The Jewish question cannot certainly be relegated only to the 20th century, but surely it was the century in which the cultural, political, economic, and social debate was the expression of a collective will to create a Nation and develop and transform it into a key country in the context of global geopolitics.

Keywords: Israel; Intelligence; Global Geopolitics, Middle East, Politics, Society, Zionism

\section{Introduction}

The notions of security and stability are central to our contemporary society. In democratic countries the same governmental legitimacy is linked strictly with security and an unexpected peril can pose an imminent or a near-future threat to democracy.

The article will evolve around the notions of Intelligence, politics, history, society, geopolitics as far as the modern and post-colonial formation process is concerned.

After the First Zionist Congress held in Basel, Switzerland, from August 29 to August 31, 1897 the theoretical framework of the State of Israel was progressively becoming a reality of facts.

The national liberation project did not develop easily, as Zionism had to tackle three fronts:

- the Jewish world;

- the international scenario;

- Palestine.

The triple action started from the British settlement in Palestine, in 1917, and lasted until the Israeli Declaration of Independence, on May 14, 1948.

During that period, three main areas of intervention were identified and focused:

- to extend the influence of Zionism within the diaspora community, particularly in the United States ("conquest of the community" tactics);

- to strengthen and expand the diplomatic activities within the League of Nations (SDN) and the international organizations, especially in the Anglo-Saxon world;

- finally, to enhance the Jewish community in Palestine with reference to economic, social, military and cultural aspects.

These combined actions have been successful thanks to a careful preliminary work.

The struggle in favour of the Jewish State led to a decisive victory in 1948 because the plan

\footnotetext{
${ }^{1}$ Pioneer in Intelligence Studies in Italy, the author's research interests focused on Intelligence, the relation with the Political Science and the Intelligence cycle. With more than 70 books published on the topics; among them: The Intelligence cycle, The History of M16, The History of the CIA, The History of the Italian Secret Services, The History of the Entity, The History of Mossad, and the History of the STASI.
} 
was designed with care, long before Great Britain took possession of Palestine.

It was during the crucial years from 1881 to 1917 that Zionism organized internally (in the Jewish world), externally (at an international level) and at regional level (in Palestine).

Those decades have marked the birth of Zionism (Dieckhoff, 1999).

As far as the third front is concerned, namely the settlement in Palestine, the first groups born after the escape from the pogroms in Russia and since the death of Tsar Alexander II, were mainly farmers.

Later on they were called Kibbutz and formed the basis of the modern State of Israel, and had a strong symbolic power.

\section{Research Questions}

As far as the research is concerned the first question is: how can we place the Jewish question in the 20th century and the creation, development and transformation of a new Nation in an international scenario?

Second question: what were the new capabilities, know-how and analysis tools that Intelligence needed in such a new and complex reality (a Nation created from an international preexisting status-quo) as to require a new approach?

\section{Research methods}

This paper uses a three-methods approach and three-phase process: discovery, coding and analysis, using a range of qualitative coding techniques.

The triple steps include:

- a discovery phase of data collection;

- a coding phase using some analytical techniques and proposed methodologies as filters;

- an analysis phase using data analys.

The article offers a number of original contributions to the scientific literature.

First, the article re-examines the history, sources and theory-building and offers alternatives to the influential theory-building framework that most scholars accept.

Secondly, it reinforces the link between Intelligence studies, history, sociology and political science.

Third, the mixed methods offer a research agenda with potential cognitive bias that can affect the "at a distance" examination.

The documents used refer to Open Source documents, archives, publications, and reliable secondary sources.

A new understanding will emerge on how we can contribute and analyze the previous and future core of the Israeli State.

The academic studies that focused on the creation of the State of Israel are interwoven with security studies due to the fact that Israel had to defend itself against aggressions from the very beginning.

The main argument is that a structured and composed Intelligence organization was already active in each and every single moment of the creation of the new Nation.

This article can thus be a contribution to the gap in the literature of the field, and its relevance is due to the fact that at the moment the evolution of the debate on the role of security and Intelligence in the first steps of the Israeli State is not much studied.

The limitation of this research is due to the fact that it should be treated with an entire volume, and not only with a brief article.

\section{The Pioneering Phase}

In the beginning the Kibbutz (Hebrew: קיבוץ) reflected a popular feeling; it can be considered as a pioneering phase, the starting point that historically corresponds to a first self-identifying sociality.

The associations in the form of kibbutz dated back to the early 20th century, and to the 
founding of Degania (south of Lake Tiberias) in 1909.

Being the first milestone of the future sovereign State and conceived in that way, the kibbutz was an initiatory reality, in a period steeped in a strong ideology, and mostly based on the land agricultural transformation and a subsistence agriculture.

The kibbutz had and has still now the following rules:

- The kibbutz is ideologically conceived as a social and economic structure, based on the principle of equality;

- The individual work is intended for the community;

- The individual work is not monetized, but quantified as the result of work;

- Decisions are taken by the General Assembly, composed of all members;

- Until a few years ago children could not live with their own families (Dagradi, Farinelli, 1992).

"Due to the lack of resources the settlers of the "First Aliya" (1882-1903) were granted a financial protection from Baron Edmond de Rothschild, who "enclosed" them in a hierarchical and paternalistic system; many of them became master builders or farmers and employed Arab workers, considered more efficient and cheap. It was a sort of colonial-style economic system, where new immigrants administered agricultural exploitations employing 'natives'.

Between 1904 and 1914 ("Second Aliya"), the arrival of about forty thousand immigrants from the Tsarist empire, moved by a socialist ideology, worsened the relations with the Arabs.

David Ben Gurion, the future founder of the State of Israel, and his entourage were in fact determined, unlike their predecessors, to establish in Palestine a completely independent Jewish society.

This goal required the construction of a Jewish independent economic infrastructure, promoting the exclusive employment of Jewish labour in the colonies" (Dieckhoff, 1999).

"In 1910 the Kibbutz became a 'collective community' where the work was performed solely by Jews. It was the paradox of Zionism: as soon as it became a national project, it cut the relations with the colonial organization, causing the Arab hostility (excluded from a Jewish self-sufficient economy).

The economic separatism stirred up the Arab anti-Zionism [...]. The immigrants of the "Second Alyah" (come into Israel) putting Arabs aside from the Palestinian society led to a completely new Nation: the Jewish one" (Dieckhoff, 1999).

The predominance of the colonial or nationalist characteristic will be an open issue among the Jews settled in Palestine, as well as a difference between the First and Second Aliya.

"The first wave of immigration did not create a significant change in the life of Jews and Palestinians of the Ottoman Palestine. The second wave coincided with the disintegration of the Ottoman Empire and its replacement with a modern political system [...]. The settlers tried to combine Jewish nationalism and socialism and discussed what should have been a priority. The debate led to the founding of the first two Palestine Zionist parties and the development of two different kinds of collective settlements, the most famous of which was the kibbutz.

Most Zionists were not interested in agriculture, nor to live in the countryside, and preferred to settle in the cities, where collectivism was not so much practiced but it was a sort of affiliation to trade unions" (Pappe, 2005).

\section{Zionism}

"After the First World War, Zionism continued to be a project motivated by national feelings.

The collectivist settlements had a national peculiarity as the landowners focused on an adapted nationalism and hoped for a large Jewish territory even if limited the flow of migrants.

This was due to the fact that they intended to employ Palestinian rather than Jewish labour, because Jewish workers were more aware of their rights" (Pappe, 2005).

Bloody riots broke out affecting the different parties.

In 1907 the "First Aliya" settlers, thanks to Baron Rothschild and the National Fund, founded a secular city different from the experiments of the Orthodox Jews in Jerusalem as well as from the collectivist experience of the kibbutz. It was the modern Tel Aviv. 
"Tel Aviv became the centre of the Zionist activity, much more than Jerusalem, and being exclusively Jewish, embodied the dream of a totally Jewish Nation [...].

To some extent Tel Aviv was the antithesis of the collectivist and socialist-like way of living, typical of the countryside settlements.

Many Jews who immigrated before 1905 were more interested in a job than in becoming farmers [...]. Those who arrived after 1905 were determined to make the settlements in the countryside the vanguard of Zionism in Palestine.

As activists of the socialist movement in Eastern Europe, they had both national and collective dreams and thus private initiative and individualism could thrive, while settlements of collective nature were mainly Jewish.

Nevetheless, violent riots against the settlers employing Arab labour burst out" (Bensoussan, 2005).

The Zionist movement at first politically (since the first Congress of 1897) and then practically (starting from 1904 and the Second Aliya), banned the colonialist ideology.

"Starting from this period we face a separate national and economic development, as well as the ban on the Arabic labour and the building of kvutzà, moshav and kibbutz" (Bensoussan, 2005).

From a symbolic and ideal point of view, the kibbutz is the starting point of the Jewish Nation.

In the modern Israeli historiography, the "new historians" as Shafir and Pappe analyzed the milestone of Zionism as a source of legitimacy for the State of Israel: that is pioneering (Shafir, 2017).

"Pioneering means adjusting Zionism to practice. Today, the pioneer's image is a cliché because it represents debased people who through their work conquered the right to a national existence [...]. The first reports have created the image of pioneers who redeem a 'wasteland', one of the most powerful Zionist commonplace as far as the research of legitimacy is concerned" (Bensoussan, 2005).

Even if the Zionist leadership had planned that a lot of people moved to Palestine after the First Aliya, it didn't happen. Therefore only a little group arrived in order to prepare the forthcoming migration.

"In order to start a mass immigration, Ber Borochov suggested that a restricted group 'willing to sacrifice' had to assume the task. A handful of pioneers and not Jewish proletariat, that had no reason to go there, would have set the first steps [...]."

Borochov theorized then the so-called chalutziut (from chalutz: pioneer), the pioneering spirit of the Second Aliya" (Bensoussan, 2005).

As Borochov, also Menachem Ussishkin in the book entitled Our program (1905) writes: "It was necessary to develop a civil service that young Diaspora Jewish volunteers could attend in Eretz Israel for three years, at the service of the Yishuv, in order to help the country.

Ussishskin creates the Nachal pioneer body (paramilitary institution for youths, before the military service) that will further develop after the indipendence" (Bensoussan, 2005).

The pioneering culture created a fracture with the colonial model (the old Yishuv) in order to generate something completely new (the new Yishuv) through the work of a "new man", a new Jew.

"For the few men and women who lived in Palestine before 1914, the desire for sacrifice was a common feeling [...]. As stated in notebooks and letters, they wanted to forge a 'new Jew' (and often used the term Ivri, namely 'Jew'), breaking with the Diaspora Jew, as if the Zionism had to reconnect with an ancient Judaism already turned into a myth.

The pioneering ethos to which they referred was a sort of a new civil religion among the new Yishuv. Such new term, emphasizing the gap between the old and new world, between chalukà and work, namely between Jew and Jewish, came from such dualism.

Pioneer (chalutz in Hebrew) is the "new man", a hero imbued with the European culture of the early 20th century and was in common with the Italian Fascism as well as the Russian Bolshevic culture of the twenties (and referred to the same anti-bourgeois philosophy).

The pioneering Zionism, aimed at creating a free, healthy, working and free-from-fear Jew rooted in his 'national home', Eretz Israel.

The pioneering spirit was referring also to the so-called Hagshama, or self-realization and it was not just a 'personal fulfilment', or individual development. The Hagshama, on the contrary, 
wanted to merge people in a sort of 'collective We' that was nothing more than a Nation" (Bensoussan, 2005).

Zionism was a European movement "that in Western Europe was undoubtedly part of the cultural heritage of the Old Continent. It is particularly clear in Max Nordau that considers the weakening of reason in Europe in the last decade of the 19th century as an hint for the forthcoming catastrophe [...]. Nationalism was a reaction to the anti-Enlightenment, and led to the final tragedy; even if it seemed that it was working for the common welfare of humanity" (Bensoussan, 2005).

Some intellectuals like Leon Pinsker and Achad Ha'am, influenced by Nordau, argued:

"[...] Nation is a 'spiritual concept". The Jewish intellectuals think that religion is an essential factor of the national ego, thus stating a secular definition of Jewishness" (Bensoussan, 2005).

Imperialism and colonialism merged into Zionism as a synthesis of the European culture.

In The Jewish State, Herzl wrote: "If His Majesty the Sultan conceded us Palestine, we could commit to give it back, to rearrange the finances of Turkey. To defend Europe from Asia we will build there a wall, an outpost of culture against barbarism" (Herzl, 1896).

With reference to those aspects, quotations taken from Herzl and Max Nordau are numerous.

Max Nordau accepted the most Eurocentric theses in the name of philanthropy and eugenics and had also foreseen the end of the Enlightened imperialism.

As he stated in 1905, the Jews were allied with the Western countries within the Arab world; they were an outpost for the control of a vast territory stretching from the Atlantic Sea to the Persian Gulf.

"England cannot allow that its positions on the Suez Canal could be endangered. Obviously, it is strong enough to defend it. Nevertheless, it cannot dislike a trusty and strong guardian over there. The Jews can be this kind of guardian over the Suez Canal. They are ready to serve England as sentinels for the Near and Middle East up to the borders with India" (Bensoussan, 2005).

When Theodor Herzl started his political and diplomatic activity, he took advantage from the aid offered by the Jews of Eastern Europe and the diplomatic support given by Great Britain.

At the First Zionist Congress in Basel, in 1897, Herzl and the Zionist ideologues "did not only discuss the creation of a Jewish Athens, but expressed the desire for a Zionist Sparta. Then the Zionist leaders realized that a nationalistic framework had to be used in order that the Jews could regain Palestine and create their own country [...]. They reintroduced the Herzl's project of a mass migration of farmers, labourers, managers, technicians, engineers and other skilled workers to Palestine [...]. The Zionist program, also known as "Basel program", was the main outcome of the First Zionist Congress. The manifesto proclaimed that 'the Zionist movement wanted to create a refuge for the Jewish people in Eretz Yisra'el; and the new country should be safeguarded from the international laws".

The Second Zionist Congress was held in 1898 and focused on the concept of colonizing the Land of Israel.

During the Third Congress, Herzl proposed to replace the quest for international legitimacy with the concept of a rent concession given by the Ottoman sultan.

"Herzl was convinced that money and influence from Europe would have induced the sultan to agree" (Pappe, 2005).

However, it did not and at the beginning it was just a political movement based on a selfdetermination program, hosting contradictory trends: there was a huge gap between the extreme left, enhancing the creation of a bi-national (Jewish-Arabic) State, and the nationalist right, claiming a Jewish State on the Jordan's shores.

"At the beginning Zionists did not even agree on their final destination: some thought about Palestine while others evoked, for example, Argentina" (Dieckhoff, 1999).

At this point, while Herzl, within the Zionist Congress seeked to create some organizations in order to finance, organize and diplomatically manage the mass emigration, other Jews mainly from Russia, headed by Chaim Weizmann and members of the so-called Lovers of Zion, begun to move to Palestine. They were also called the "territorial Zionists" and wanted to carry out "in Israel an ideology merging romantic nationalism and revolutionary socialism" (Pappe, 2005).

The "territorial Zionists" interacted with the British in order to buy the land and obtain a diplomatic and political support. 
The most important funder and supporter in this phase was Baron Edmond de Rothschild (who had not financed Herzl) that wanted to withdraw from the project due to some disagreements with the settlers.

Herzl proposed to create two bodies, intended as "instruments for the realization of the Jewish national design" (Herzl, 1896).

The first one, the Society of Jews, would have been a 'constituent' political institution endorsed to obtain, with the support of the international community, sovereignty over a given territory.

At that time, Theodor Herzl had not yet chosen between Palestine and Argentina.

The second one, the Jewish Company, was intended to put into action the Zionist program "organizing the transfer, purchasing the land, and giving to the new country the economic and social foundations" (Dieckhoff, 1999).

After various Zionist Congresses "the Zionist organization, striving to achieve in Palestine a publically recognized and legally guaranteed national home, was then formed. The Jewish Colonial Bank and the Jewish National Fund supported such goal" (Dieckhoff, 1999).

The English recognized the Jewish Nation for several reasons, but mainly in order to have an ally in their expansionism from Egypt to the East.

Herzl argued that "in London it got off to a good start. In Western Europe, the English Judaism was in fact receptive to Zionism, as it has been prepared by the Lovers of Zion. In case of a major immigration of Jews from Eastern Europe, Great Britain would have tried to divert them to other destinations" (Herzl, 1896).

Theodor Herzl realized that he should have considered some areas out of Palestine (for example the Sinai or Cyprus) as a destination for a Jewish national home.

After the pogroms that affected Russia in 1903, it was necessary a solution to relieve the Jews living in Russia.

For this reason, "in the summer of 1903 the Government of Her Majesty established a Jewish colony in Uganda" (Dieckhoff, 1999).

The proposal was discussed and rejected in 1905 by the same Zionist organization but all the same represented an important date in the history of the Zionist movement.

"For the first time, Jews were officially recognized as belonging to an independent Nation; for the first time, the Zionist Organization appeared as a legitimate interlocutor and a recognized mediator with the British leaders.

Theodor Herzl's negotiations prepared the ground for the Balfour Declaration of November 2, 1917" (Dieckhoff, 1999).

Finally, the British colonial interests in the Middle East dating from the occupation of Egypt in 1882 made Herzl's dream come true.

"If the Jews, like the Anglican missionaries, enhanced the British expansion in Palestine, there was no reason to consider them as welcomed. The pro-Zionist attitude of the British policy in the Middle East [...] was the result of a neo-colonial vision of the world and of an ancient theological concept connecting the Jews moving to Palestine with the second coming of the Messiah. Herzl was able to convince the colonialists and the British evangelicals and gave to the British government the opportunity of transforming the arid zone of El-Arish, near Gaza, into a Zionist oasis" (Pappe, 2005).

\section{The First World War}

As fas as the domestic situation was concerned, settlements met a strong opposition only after the First World War.

Under the "capitulations system" of the Ottoman Empire (trade concessions and legal privileges granted to the Europeans and extended, in the last years of the Ottoman Empire, to Christians and Jews living there), the Jews bought some other land.

At the outbreak of the First World War, the Ottoman Empire sided with Austria and Germany and through the official representative, Aharon Ahronson, the Jews tried to give support to the possible winner of the war; anyway the Turks refused. 
On the other hand "the British were willing to accept their cooperation in the Intelligence field, so as to strengthen the relationship between Zionism and the British. The Zionists were excellent in timing. The training in data collection and military life was important to Zionists when the army of the Jewish community of Palestine was established.

The army grew in the 1920s, and became a powerful independent security organization acting without the British support" (Pappe, 2005).

\section{The Sykes-Picot agreement}

The political future of Palestine was decided during the negotiations between England and France in 1912 (Sykes-Picot agreement).

The two Nations divided the entire Arab Middle East and replaced the old Ottoman provinces with new political entities.

Lebanon and Syria remained under the French rule, while the southern zone and Iraq became a British dominion.

Palestine was to become an Anglo-French colony, but "at that time, Palestine was considered as a buffer zone to protect the Suez Canal, and the British occupation of 1917 completed the annexation of the Sinai Peninsula to Egypt started in 1906" (Pappe, 2005).

At the beginning of the war, the Zionist leadership had promptly tried to persuade the British government that the establishment of a Jewish colony in Palestine represented a steady interest.

In the UK, some political leaders as the Foreign Minister Arthur Balfour committed to help the new president of the Zionist movement, Chaim Weizmann, in his propaganda campaign.

Finally, they succeeded in changing the British positions.

"Their main success consisted in the creation of a stable pressure group composed of public personalities, both Jewish and not, referring to the Rothschild family. In 1916, the government began formal negotiations with the leaders of the Zionist movement. On November 2, 1917 Lord Balfour made public the British commitment in the foundation of a Jewish Nation in Palestine" (Pappe, 2005).

In November 1917, Palestine was left under the British military occupation and the French soldiers fled away from the region.

The British intended to share with nobody else such sovereignty, while the Sykes-Picot agreement was about to be applied also to the rest of the Middle East.

Britain allowed the French troops to enter Lebanon in 1918, from where they invaded Syria in 1920.

"For the Zionist movement, the First World War was a turning point. The Balfour Declaration, as the similar positions taken by the Allies, confirmed the Zionist impression to be riding high" (Pappe, 2005).

Notwithstanding such a political and diplomatic authority, the Arab population did not express a unified nationalist vision to contrast the Jewish "national home" and tensions grew and exploded for the first time in 1920.

"On April 4, in Jerusalem, some bloody riots burst for the first time between Arabs and Jews. The latter accused the British soldiers of having let a pogrom happen in the same Tsarist way. The Arabs claimed that some Jewish provocations originated the clashes. The British army concluded the investigation by accusing the Zionists living in Palestine" (Pappe, 2005).

Sir Herbert Samuel was appointed British High Commissioner in Palestine and as a member of the Jewish aristocracy he supported Zionism.

After the French arrived to Damascus the idea of an Arab unitarian State in which Palestine would have been the so-called "Southern Syria" was given up.

The nationalist Palestinians met in the Christian-Arab Congress in Haifa in December 1920, and called themselves "Palestinian Arabs".

"Sir Herbert Samuel refused to recognize the organization and the anti-Jewish riots in Jaffa provoked in 1921 the British repression of the Arab movements" (Pappe, 2005).

The High Commission was in favour of a Jewish-Arab Palestinian institution based on the separation of the communities, in which the British would have played the role of arbitrators. 


\section{The White Paper}

In 1922, after the publication of the White Paper on Palestine, the British government clarified its own position.

"Great Britain does not intend to turn Palestine into a Jewish State, but wants to allow the realization of a Jewish Nation that will not harm the Arab inhabitants; the Jewish presence in Palestine is not only tolerated but declared as legitimate, even if the laws provide a strict control of the Jewish immigration on the basis of the country economic absorption.

The League of Nations ratified the document on July 24, 1922" (Pappe, 2005).

While Zionists accepted the decision in order to gain time, the Arabs rejected the proposals as it meant the acceptance of the Balfour Declaration.

The years from 1923 to 1929 were relatively calm; the Zionists were facing a deep economic crisis and a consistent immigration in the years dating from 1924 to 1926, while the Arabs formulated their national ideology.

The holy places, like the Wailing Wall, and the whole religious complex of Haram al Sharif, the site of the ancient temple of Jerusalem, were involved in a political and ideological struggle between the two factions, that led to the riots of 1929.

In 1928 John Chancellor, the new High Commissioner, stated: "the interests of Great Britain can be facilitated by a decrease in Zionist activities. The new White Paper, written after the investigations carried out to examine the motivations of the 1929 clashes, argues the necessity of restricting the site of the Jewish national home. However, Haim Weizmann made each and every effort to get from the British Prime Minister, Ramsay McDonald, the disavowal of the White Paper, in 1931" (Pappe, 2005).

In 1933, in Haifa the crowd railed not against the Jews but rather against the British. Tensions built up and finally the unrest erupted into a riot.

The High Commissioner Wauchope tried to restore order by proposing the formation of an assembly representing the entire Palestinian population, but the Jews objected even if they were only a quarter of the total population.

Nevertheless the British surrendered to the Zionist pressure.

In April 1936, after some clashes, the situation exploded again; the Arabs proclaimed a general strike, while the villagers began to rise up against the British.

Working with both negotiations and repression, Wauchorpe promised the creation of a Royal Commission to reconsider the Palestinian dossier.

In July 1937 the Royal Commission proposed a partition of Palestine, moving the Arab population outside the Jewish area with a financial compensation.

The Zionists accepted the British proposal as it meant a State that extended to the whole Palestine. The Arabs rejected it, as it was in contradiction to the British statements of 1920.

In October 1937, an insurrection broke out in the whole Palestine and "it was probably the most serious anti-colonial revolt against the British Empire between the two world wars" (Pappe, 2005).

The British took advantage of the conflict between two Palestinian clans to weaken the Arabs, using the Nashashibi against the Husseini (leaders of the revolt).

In the third White Paper of 1939 a drastic limitation of the Jewish emigration and some land transactions were announced.

From the outbreak of the Second World War to 1944 there was a period of peace.

A large number of British war orders and commissions established in the country and both Arabs and Jews took benefit from them.

The Jewish opposition to the third White Paper was fierce; many Jews escaping from the German extermination camps were willing to enter Palestine and in the meantime the so-called Zionist revisionist groups (Stern and then Irgun) were created and started to attack the British.

"After the war, in 1945, the world faced with the power of evil; the Holocaust was there, with six million Jews massacred. After the Holocaust, nothing was ever the same, not even the Jewish question and the Zionism [...].

The Arab League, created in 1945, and supported by the British did not accept the 
immigration of the Holocaust survivors any more (Harrison Report, 1945), even if confirmed the White Paper of 1939 (1500 entries per month).

After the Exodus affair (58 out of the 63 illegal vessels that tried to get close to the Palestinian coasts were intercepted by the British) and the two-party system that came out after the end of the second World War, Zionism had to be reformulated.

In the years from 1945 to 1948 Zionists clashed several times with the British, and the struggle between Arabs and Yishuv grew considerably.

Among these episodes, the assassination of the Minister of the Colonies, Lord Moyen, in 1944 by the Stern group [...] and the Black Saturday on 26 June, 1946 are to be remarked.

That day, the British forces invaded the Jewish Agency in Jerusalem, arrested 2500 people and executed 7 members of the Irgun.

The reaction was strong; on July 22, 1946, after a warning, the Irgun blew up a wing of the King David Hotel, seat of the British headquarters and 90 people died.

The unsustainability of that situation led the British government to declare the internationalization of the 'Palestine affair' and on April 20, 1947 submitted it to the General Assembly of the United Nations" (Codovini, 2009).

\section{The UN General Assembly Resolution 181}

After the General Assembly Resolution 181 dated November 29, 1947 the United Nations stated the end of the British mandate in Palestine and the partition of Palestine into two independent and sovereign States, the Arab and the Jewish, while Jerusalem was subject to an international administration by the same United Nations.

The Arab response was negative; the Arab Higher Committee and the governments of the Arab States rejected the United Nations proposal, expressing their opposition to the establishment of a Jewish State in Palestine, against which they felt entitled to use violence.

The British left Palestine on May 1, 1948.

"In this new context [...], the various Jewish bodies (Zionist Organization, Jewish Agency, Jewish National Council), within the coordinates set by the United Nations, tried to take charge of the various administrative departments to reinforce the State, and the Arabs, on December 8, 1947, through the Arab League, declared a 'holy war' against Israel.

[...] The Yishuv was made up of 630,000 members, while the Arab population was 1,200,000" (Codovini, 2009).

Violence inevitably erupted and the Jews attacked on the basis of the so-called Plan Dalet, "which provided for the assumption of control in strategic areas.

On April 6, the Nachshon operation began with the intention of creating a passage to Jerusalem.

On April 9, the Irgun and the Stern reactions to the Arab attacks were very violent: 254 victims in the Arab village of Deir Yassin [...].

After the Arab bombing of the Hadassah Hospital on April 13, 1948, where 78 Jews were killed, and in Kfar Etzion on May 12, with 100 Jews killed, finally on May 14, 1948 (Friday at 16 pm, at the expiry of the British Mandate), Ben Gurion proclaimed the birth of the State of Israel singing the Hatikva (The Hope), the anthem of the Zionist movement and of the new-born Nation.

Ben Gurion at that moment was chairman of the Jewish Agency and the undisputed leader of the Zionist movement" (Codovini, 2009).

\section{Ben-Gurion and the Israeli Declaration of Independence}

The State of Israel was immediately recognized by the United States and the USSR.

The Prime Minister was Ben-Gurion and the Knesset appointed Chaim Weizmann as the first President.

"Only eight hours after the Declaration of Independence, the Arab armies invaded the legal territory of Israel: the Lebanese from the North, the Syrians from the North-West, the troops of Transjordan and Iraq from the centre and the Egyptians from the South. 
It was the beginning of the First Arab-Israeli War and a long conflict was born that is still pending in the present days" (Codovini, 2009).

\section{Conclusions}

As a conclusion, we can state that the first steps of the State of Israel are a valid example and can be cited for how security and Intelligence are vital to modern democracies.

Nowadays Intelligence has to address the new challenges of a globalized, computerized, multiethnic and multicultural society.

In such a complex international system contemporary Intelligence needs unquestionably a new holistic approach.

\section{References}

Andrew, C., (2009) The Defence of the Realm, London, Allen Lane.

Bensoussan, G., (2007), II sionismo. Una storia politica e intellettuale (1860-1940), vol. II, Torino, Giulio Einaudi. Codovini, G., (2009), Geopolitica del conflitto arabo israeliano palestinese, Milano, Bruno Mondadori.

Colonnna Vilasi, A.,(2011), Manuale di Intelligence, Reggio Calabria, Citta' del Sole ed.

Dagradi, P. \& Farinelli, F., (1992) II mondo arabo e islamico, Torino, Utet, Torino.

Dieckhoff, A., (1999), Le tre battaglie del sionismo, in Cardini, F. (ed.), Israele. Da Mosè agli accordi di Oslo, Bari, Dedalo.

Dieckhoff, A., (1999), Il sionismo è l'ultimo progetto coloniale?, in Cardini, F. (ed.), Israele. Da Mosè agli accordi di Oslo, Bari, Dedalo.

Grayzel, S., (1964), Jewish History, Rome, Jewish Foundation for Youth.

Herzl, T.,(1896), The Jewish State, www.jewsvirtuallibrary.org (September 30, 2017)

Laurens, H., (1999), Il fallimento del mandato inglese, in Cardini, F., (ed.), Israele. Da Mosè agli accordi di Oslo, Bari, Dedalo.

Lituinoff, B., (2002), La lunga strada per Gerusalemme, Milano, Saggiatore.

Pappe, I., (2005), Storia della Palestina moderna, Torino, Giulio Einaudi.

Rhett, M.A., (2015), The Global History of the Balfour Declaration: Declared Nation, Londra, Routledge.

Rodinson, M., (1986), Israele e il rifiuto arabo, Milano, Feltrinelli.

Shafir, G., (2017), A Half Century of Occupation: Israel, Palestine, and the World's Most Intractable Conflict, Oakland, University of California Press.

Turnberg, L., (2017), Beyond the Balfour Declaration, Londra, Biteback Publishing. 